\title{
Penggunaan Media Pembelajaran Swimming board dalam Pengembangan Afektif
}

\author{
Rahmat Permana \\ Universitas Muhammadiyah Tasikmalaya \\ Email: rahmat.pgsd@umtas.ac.id
}

\begin{abstract}
Abstrak: The problem is the reference authors in this research is to reveal the influence of the media or teaching aids in swimming. The study was conducted in Bandung ganesha School mandala swimming with the sample at the level swimmers who have not received a base class breaststroke swimming lessons. The purpose of this study was to determine the influence of the media in the development of swimming board psychomotor, cognitive and affective. The method used in this study are pre experimental method with a population of 10 people swimmer basis, the determination of the total sample population of the swimmers who have not given breaststroke swimming lessons numbered 10 people. After treatment of the sample given the findings show that the use of swimming board significantly influence the development of breaststroke swimming skills with Sig. 0.000>0.05.
\end{abstract}

\section{Pendahuluan}

$\mathrm{H}$ asil belajar keterampilan gerak dalam proses pembelajaran pendidikan jasmani salah satunya adalah keterampilan gerak dasar renang. Alasan mengapa cabang renang dapat digunakan untuk mencapai tujuan pendidikan jasmani karena renang memiliki banyak manfaat. Manfaat tersebut diantaranya dapat membantu pertumbuhan dan perkembangan tubuh, bersosialisasi dan berinteraksi dengan orang lain, menambah kepercayaan pada diri sendiri dan dapat digunakan sebagai kegiatan rekreatif karena pengaruh dingin dapat menyegarkan tubuh dan perasaan.

Model pengembangan gerak dasar renang di sekolah dasar harus disesuaikan dengan tahap pertumbuhan dan perkembangan anak, agar hasil yang dicapai sesuai dengan tujuan pembelajaran yang diinginkan. Banyak berita-berita di media cetak maupun elektronik mengulas tentang kerugian ketika anak tidak bisa berenang, selain berdampak pada kesehatan berdampak pula pada keselamatan jiwa, data yang dikeluarkan oleh Burns (2013) mengemukakan bahwa pada tahun 2011, 407 orang meninggal tenggelam di air akibat tidak bisa berenang, ironisnya usia mereka yang meninggal antara tujuh sampai sebelas tahun, ini karena kurangnya kelas berenang pada usia sekolah dasar. Dikhawitirkan juga di Indonesia hal ini bisa saja terjadi apabila aktivitas renang memang kurang dalam pelajaran pendidikan jasmani karena faktor alokasi waktu yang disediakan sekolah kurang. Maka masalah ini harus segera ditangani dengan cara menambah aktifitas akuatik anak pada perkumpulan renang untuk menjadi anggota.

Dalam cabang renang terdapat beberapa gaya yang digunakan, salah satunya adalah gaya dada. Ditinjau dari gerakannya renang gaya dada mempunyai banyak keunggulan dari gaya renang yang lain, diantaranya dari gerakan yang alami sehingga dengan mudah orang mempelajarinya, bernapasnya tidak sulit sehingga tidak merepotkan untuk jarak renang yang jauh. Dalam jurnal olahraga Supriyanto (2011) 
Menjelaskan tentang manfaat yang ada pada aktivitas olahraga renang tersebut antara lain adalah untuk memelihara dan meningkatkan kebugaran, menjaga kesehatan tubuh, untuk keselamatan diri, untuk membentuk kemampuan fisik seperti daya tahan, kekuatan otot serta bermanfaat pula bagi perkembangan dan pertumbuhan fisik anak, untuk sarana pendidikan, rekreasi, rehabilitasi serta prestasi.

Renang gaya dada merupakan gaya berenang yang mudah dipelajari, ini berdasarkan pengalaman penulis ketika mengajar anak-anak usia sekolah dasar pada klub Mandala Ganesha Bandung, memang betul ketika seorang anak ditanya gaya renang apa yang paling disenangi dan mudah mereka menjawab gaya dada atau gaya katak. Sesuai dengan pendapat Thomas (2006) gaya dada memiliki batasan dan peraturan yang lebih lengkap dan didefinisikan lebih rinci dari pada gaya-gaya yang lain dalam buku peraturan, namun gaya dada adalah gaya yang mudah dan nyaman untuk dilakukan. Pendapat Thomas ini sesuai dengan apa yang terjadi di lapangan pada saat ini bahwa gaya dada atau katak dalam pelaksanaan proses pembelajaran harus terperinci dengan baik dari mulai sikap meluncur sampai pada gerakan koordinasi keseluruhan.

Sedangkan Wynman pada tahun 1538 (dalam Murni 2000): "Bedanya antara perenang dengan seekor katak bahwa sikap meluncur perenang dilakukan dengan dua kaki dan kedua lengan lurus, sedangkan pada katak sikap seperti itu tidak dijumpai". Pendapat tersebut menunjukan bahwa berenang gaya katak dikatakan mudah dan nyaman karena gerakanya menyerupai seekor katak yang sedang berenang.

Akan tetapi banyak ditemukan anak yang kesulitan pada saat melakukan proses pembelajaran renang gaya dada. Pertama, anak sulit mengapung untuk mendapatkan posisi yang lurus sejajar dengan permukaan air apabila tidak ditopang dengan alat bantu. Kedua, tanpa alat bantu yang baik anak kesulitan untuk melakukan teknik dasar gaya dada dari mulai meluncur, gerakan kaki, lengan dan koordinasi, empat tahapan gerakan ini bisa dilakukan dengan baik jika ada penopang badan yang stabil pada anak. Ketiga, hasil belajar renang gaya dada tanpa alat bantu akan rendah karena tidak adanya rasa ingin tahu siswa terhadap fungsi media belajar untuk renang. Keempat, tanpa alat bantu tidak mungkin ada variasi-varias mengajar yang dilakukan oleh guru pada saat proses pembelajaran renang gaya dada, tanpa alat bantu siswa akan dibantu oleh guru dengan cara dipegang untuk mengapung artinya proses ini akan memakan waktu yang lama dan berdampak pada hasil belajar keterampilan renang gaya dada, sejalan dengan Suherman (2001) beberapa macam alat bantu renang dapat digunakan untuk memperkaya bahan ajar, sehingga waktu aktif belajar dapat dimanfaatkan secara penuh. Artinya, dengan dukungan alat bantu, anak tidak banyak menunggu giliran atau harus satu-satu dilayani oleh guru. Alat bantu akan sangat besar manfaatnya pada situasi kelas yang banyak. Selain itu alat juga bermannfaat untuk menjaga keselamatan siswa.

Maka rendahnya hasil belajar keterampilan renang gaya dada atau katak karena memang perlu adanya suatu alat bantu yang nyaman dan efektif dalam belajar keterampilan renang yang terpenting bahwa alat bantu tersebut tidak menjadikan hambatan pada perenang pemula, namun justru akan memberikan bantuan yang memudahkan perenang tersebut dalam belajar berenang.

$$
\text { Gerlach \& Ely (dalam Arsyad) }
$$

"Mengatakan bahwa media apabila dipahami 
secara garis besar adalah manusia, materi atau kejadian yang membangun kondisi yang membuat keterampilan atau sikap". Berbagai cara dapat dilakukan didalam pemberian materi pembelajaran renang gaya dada, termasuk salah satunya alat bantu Swimmig board atau papan pelampung.

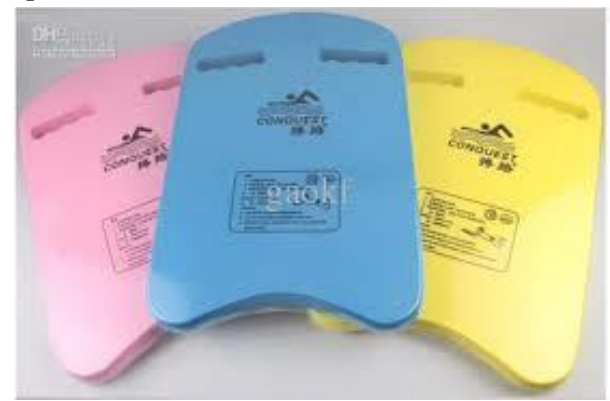

Gambar 1

\section{Media Renang Swimming board (Papan Pelampung)}

(Sumber: www.goswim.com)

Fungsi dari swimming board ialah untuk menopang berat tubuh seseorang ketika belajar gerakan renang sehingga dapat mengurangi berat tubuh. Berbentuk persegi dan terbuat dari karet ataupun bahan plastik, pada bagian atas terdapat pegangan untuk memudahkan seseorang dalam melakukan gerakan kaki agar pelampung tidak terlepas. Adapun keuntungan dan kerugian dari penggunaan swimming board yang dikemukakan Triaplianto (2010) ialah sebagai berikut :

Keuntungan mengajar renang gaya dada dengan menggunakan alat pelampung antara lain :

1. Frekwensi latihan lebih banyak karena tiap perenang satu pelampung;

2. Perenang lebih senang, karena lebih cepat mengetahui hasil yang didapatkan dengan gerakan yang berpindah tempat;

3. Perbaikan gaya akan lebih mudah karena pelampung akan membantu perenang pemula untuk membuat posisi streamline;

4. Akan cepat menguasai bagian-bagian dari renang.
Sedangkan Kerugian dari mengajar renang gaya dada dengan alat pelampung antara lain :

1. Perenang akan merasa kurang berani, karena harus melakukan sendiri dalam tahap permulaan;

2. Perbaikan tidak dapat dilakukan langsung;

3. Perenang harus punya keahlian dalam mengendalikan pelampung;

4. Harus menyediakan alat bantu pelampung. Sedangkan menurut teori Corleet (dalam Boyke 2013) :"Swimming board ialah pembelajaran renang dengan menggunakan papan pelampung sangat efisien dan efektif, karena pada saat bergerak papan pelampung dapat mengurangi berat tubuh, sehingga gerakan tungkai atau lengan lebih ringan".

Dari pendapat diatas jelas bahwa papan pelampung memberikan kemudahan untuk mengapung karena berat tubuh ditopang oleh pelampung dan untuk belajar gerakan tungkai dan lengan gaya dada akan lebih ringan, tetapi dalam hal untuk meningkatkan keterampilan renang gaya dada belum diuji serta masih ada 
keraguan dikarenakan berdasarkan pengamatan ketika mengajar renang penggunaan papan pelampung khususnya ketika belajar gerakan kaki dada perenang sering sekali terguling kekanan dan kekiri, ini yang mendasari penulis untuk memakai papan pelampung dalam meningkatkan keterampilan renang gaya dada.

\section{Metode}

Penggunaan metode yang tepat dalam suatu penelitian ilmiah sangat menentukan tercapainya tujuan pemecahan masalah dalam penelitian. Oleh karena itu diperlukan suatu metode tertentu agar data dapat terkumpul dan dapat digunakan dalam sebuah penelitian, biasanya disesuaikan dengan tujuan yang ingin dicapai dalam sebuah penelitian. Seperti diungkapkan Surakhmad (1985) "Metode merupakan cara utama yang dipergunakan untuk mencapai tujuan". Penggunaan metode penelitian tergantung pada permasalahan yang akan dibahas, dengan kata lain harus dilihat dari efektivitasnya, efisiensinya dan relevansi metode penelitian tersebut. Suatu metode dikataan efektif apabila selama pelaksanaan dapat terlihat adanya perubahan positif menuju tujuan yang diharapkan, dan suatu metode dapat dikatakan efisien apabila penggunaan waktu, fasilitas, biaya dan tenaga dapat dilaksanakan seminimal mungkin tetapi dapat mencapai hasil yang maksimal.

Bentuk dan jenis dari metode menurut Tuckman dalam Riduwan (2008) bahwa, terdapat empat bentuk metode yaitu "preexperimental, true experimental, factorial dan quasi experiment'. Senada dengan Tuckman, Sugiono (2009) membagi empat jenis metode penelitian ekperimen yaitu "pre-ekperimental, true ekperimental, factorial ekperimental, dan quasi ekperimental.

Metode dalam penelitian ini menggunakan metode pre-eksperimen dengan desain kelompok tunggal. Menurut Lutan, et.al (2007) menjelaskan tentang pre-eksperimen ialah "desaindesain kelompok ini dikatakan lemah, karena desain ini tidak memberikan kontrol dari adanya ancaman terhadap validitas internal". pemilihan ini berdasarkan situasi satu variabel dan sampel penelitian yang tidak terdapat kelompok kontrol, terdapat satu kelompok eksperimen yaitu kelompok penggunaan media swimming board.

Agar penelitian ini berjalan dengan semestinya maka diperlukan pengumpulan data untuk memperoleh hasil akhir maka diperlukan suatu alat ukur sebagai pengumpul data yang sesuai berupa tes. Adapun tes atau pengujian didefinisikan sebagai suatu prosedur sistematis dalam mengamati satu atau lebih karakteristik seseorang khususnya terkait ability (kemampuan) dan capability (kecakapan) Ali (2011). Adapun alat yang digunakan dalam penelitian ini terdapat tiga instrumen penelitian yang mengadopsi dari Mulyanto (2010) tesis pada Universitas Pendidikan Indonesia dan termuat pada jurnal PGSD Universitas Pendidikan Indonesia yang berjudul Managemen Pembelajaran Metode Block Practice dan Prinsip DAP terhadap Hasil Belajar Keterampilan Renang Gaya Dada Sekolah Dasar. Adapun instrumen yang tercantum yaitu penilaian Sikap

Penilaian afektif (sikap) siswa adalah untuk mengetahui sampai sejauh mana sikap siswa pada saat mengikuti proses pembelajaran renang gaya dada dengan menekankan pada aspek sosial siswa, dilakukan pengajar dengan pengamatan selama mengikuti kegiatan proses belajar mengajar. 


\begin{tabular}{|c|c|c|c|c|c|c|c|}
\hline \multirow[b]{2}{*}{ No } & \multirow[b]{2}{*}{$\begin{array}{l}\text { Nama } \\
\text { Siswa }\end{array}$} & \multicolumn{5}{|c|}{ Aspek yang diamati } & \multirow[b]{2}{*}{ Total Skor } \\
\hline & & 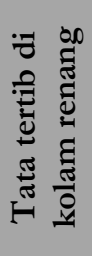 & 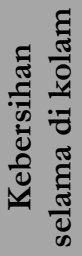 & ص્ટ & 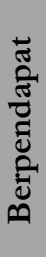 & 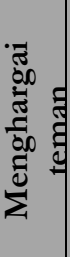 & \\
\hline & & & & & & & \\
\hline & & & & & & & \\
\hline & & & & & & & \\
\hline & & & & & & & \\
\hline & & & & & & & \\
\hline & & & & & & & \\
\hline
\end{tabular}

Terdapat lima aspek sosial yang terdapat pada tabel di atas yang diamati sebelum diberi perlakuan dan sesudah diberi perlakuan, dengan

\section{Hasil}

pemberian skor satu sampai empat berpedoman pada deskripsi indikator.

Tabel 4

Uji-T Sampel Berpasangan Tes Awal Dan Tes Akhir Pengembangan Psikomotor

\begin{tabular}{|r|c|c|c|c|c|c|c|c|}
\hline & Mean & $\mathrm{N}$ & $\begin{array}{c}\text { Std. } \\
\text { Deviation }\end{array}$ & $\begin{array}{c}\text { Std. Error } \\
\text { Mean }\end{array}$ & $\mathrm{T}$ & Df & Sig & ket \\
\hline Pair 1 sebelum & 10.20 & 10 & 1.619 & .512 & 15.019 & 9 & .000 & signifikan \\
sesudah & 18.10 & 10 & .568 & .180 & & & & \\
\hline
\end{tabular}

Pada tabel di atas terlihat bahwa rata-rata diberi perlakuan terjadi peningkatan sebesar sebelum diberi perlakuan dengan menggunakan 18.10 . media swimming board ialah 10.20, dan setelah

Tabel 4.1

Uji-T Sampel Berpasangan Tes Awal Dan Tes Akhir Pengembangan Kognitif

\begin{tabular}{|r|c|c|c|c|c|c|c|c|}
\hline & Mean & $\mathrm{N}$ & $\begin{array}{c}\text { Std. } \\
\text { Deviation }\end{array}$ & $\begin{array}{c}\text { Std. Error } \\
\text { Mean }\end{array}$ & $\mathrm{T}$ & $\mathrm{Df}$ & Sig & ket \\
\hline Pair 1 sebelum & 8.10 & 10 & 1.619 & .512 & 15.019 & 9 & .000 & signifikan \\
sesudah & 11.90 & 10 & .568 & .180 & & & & \\
\hline
\end{tabular}


Pada tabel di atas terlihat bahwa rata-rata sebelum diberi perlakuan dengan menggunakan media swimming board ialah 8.10, dan setelah diberi perlakuan terjadi peningkatan sebesar 11.90 .

Tabel 4.2

Uji-T Sampel Berpasangan Pengembangan Afektif

\begin{tabular}{|r|r|r|r|r|}
\hline & Mean & N & Std. Deviation & \multicolumn{2}{|c|}{ Std. Error Mean } \\
\hline Pair 1 Sebelum & 10.40 & 10 & 1.838 & .581 \\
& 16.90 & 10 & 1.524 & .482 \\
Sesudah & Pada tabel di atas terlihat bahwa rata- hlm.11) bahwa: "Swimming board" ialah
\end{tabular}

rata sebelum diberi perlakuan dengan menggunakan media swimming board ialah 10.40, dan setelah diberi perlakuan terjadi peningkatan sebesar 16.90

\section{Pembahasan}

Dalam penelitian ini, penulis ingin mengetahui pengaruh media swimming board. Hasil penelitian ini menunjukan bahwa penggunaan media swimming board memberikan pengaruh yang positif terhadap keterampilan renang gaya dada. Rata-rata dari hasil aspek keterampilan dalam penggunaan media swimming board sebelum diberikan treatment ialah 10.200 dan setelah diberikan treatment selama 16 kali pertemuan menjadi 18.100 rata-rata setiap anggota kelompok swimming board. Dalam paired samples test dinyatakan ada kenaikan angka sebesar 7.900 .

Dalam hipotesis awal menunjukan terdapat pengaruh dalam penggunaan swimming board terhadap keterampilan renang gaya dada dengan kenaikan sebesar 7.900 dengan nilai probabilitas $0.10>0.05$ ini menunjukan bahwa terdapat pengaruh yang signifikan dalam penggunaan swimming board terhadap hasil belajar keterampilan renang gaya dada. Hasil penelitian ini sesuai dengan teori yang dikemukakan oleh Corlett yang diterjemahkan oleh Boyke (2011, pembelajaran renang dengan menggunakan papan pelampung sangat efisien dan efektif, karena pada saat bergerak papan pelampung dapat mengurangi berat tubuh, sehingga gerakan tungkai atau lengan lebih ringan". Teori tersebut menjelaskan bahwa untuk gerakan tungkai dan lengan pada saat melakukan teknik dasar gaya dada swimming board dapat mengurangi berat tubuh tentu saja akan mempermudah siswa dalam belajar renang gerakan tangan dan tungkai.

Penggunaan swimming board dari segi fungsi juga terdapat beberapa keunggulan menurut Triaplijianto (2010, hlm.2) terdapat lima kelebihan pada saat proses pembelajaran renang menggunakan swimming board yaitu:

1. Frekwensi latihan lebih banyak karena tiap perenang satu pelampung;

2. Perenang lebih senang, karena lebih cepat mengetahui hasil yang didapatkan dengan gerakan yang berpindah tempat;

3. Perbaikan gaya akan lebih mudah karena pelampung akan membantu perenang pemula untuk membuat posisi streamline;

4. Akan cepat menguasai bagian-bagian dari renang.

Dengan metode bagian maka penggunaan pelampung akan lebih terarah dalam segi fungsi 
seperti penggunaan dalam gerakan kaki gaya dada, perenang dasar sangat nyaman dalam mengapung sehingga jika melakukan gerakan kaki terasa lebih ringan, maka akan berdampak pada teknik dasar keterampilan renang gaya dada menjadi lebih terampil dari segi gerakan.

Adapun kekurangan dalam penggunaan swimming board yang dikemukakan oleh Triaplianto (2010, hlm.2), yaitu:

1. Perenang akan merasa kurang berani, karena harus melakukan sendiri dalam tahap permulaan;

2. Perbaikan tidak dapat dilakukan langsung;

3. Perenang harus punya keahlian dalam mengendalikan pelampung;

4. Harus menyediakan alat bantu pelampung;

5. Harus mengurusi alat yang dipergunakan.

Dalam lima poin kekurangan tersebut penulis menilai bahwa tidak secara signifikan berdampak pada hasil belajar keterampilan renang yang dicapai oleh setiap siswa, seperti pada poin pertama perenang akan kurang berani karena harus melakukan sendiri dalam tahap permulaan, jika dilihat kenaikan yang dicapai setelah pemberian treatment dampak tersebut tidak menjadi masalah karena kenaikan sebesar 7.900 diyakini penulis sudah menutupi kekurangan lima poin yang dikemukakan.

Sedangkan dari hasil aspek kognitif pre-test rata-rata penggunaan alat tersebut mempunyai angka rata-rata 8.1 dan pada tes akhir ada peningkatan 12.2 pada kelompok swimming board ini menunjukan bahwa terdapat pengaruh terhadap hasil belajar kognitif. Sesuai dengan Tahapan perkembangan kognitif menurut Piaget yang mengemukakan perkembangan anak-anak dengan empat tahapan, terutama yang menyangkut perkembangan kognitifnya. Empat tahapan itu adalah tahap sensorimotor yang berlangsung dari usia 0-2 tahun, tahap praoperasional yang berlangsung dari usia 2-7 tahun, tahap operasional konkrit berlangsung pada usia 7-12 tahun, dan tahap operasional formal, yang berlangsung pada usia 12 tahun sampai usia dewasa. Sampel pada penelitian ini berada pada tahap operasional konkrit.

Pada aspek afektif hasil pre-test rata-rata penggunaan swimming board sebesar 10.4 dan pull buoy sebesar 9.3 disetiap kelompok dan pada tes akhir ada peningkatan 14.9 pada kelompok swimming board dan pull buoy sebesar 15 ini menunjukan bahwa kedua media berpengaruh terhadap hasil belajar afektif. Menurut penulis bahwa peningkatan kemampuan afektif tidak terlepas dari kecakapan kognitif yang tinggi ketika anak mempunyai kemampuan kognitif yang tinggi maka akan tampak kemampuan afektifnya.

Menurut Sudjana (2004), ranah afektif ialah "ranah yang berkaitan dengan sikap dan nilai. Beberapa pakar mengatakan, bahwa sikap seseorang dapat diramalkan perubahanperubahannya bila seseorang telah memiliki penguasaan kognitif tingkat tinggi". Dari pernyataan tersebut jelas bahwa dalam pembahasan sebelumnya mengenai kemampuan kognitif dalam penelitian ini terdapat pengaruh dari penggunaan media swimming board sehingga berdampak pada ranah afektif.

Lebih lanjut Menurut Syah (1995), "Ranah kognitif sangat erat kaitannya dengan ranah afektif. Pengembagan ranah kognitif pada dasarnya membuahkan kecakapan kognitif dan juga menghasilkan kecakapan afektif. Sebagai contoh, seorang guru yang piawai dalam mengembangkan kecakapan kognitif, maka berdampak positif pula terhadap ranah afektif".

\section{Simpulan}

Berdasarkan hasil pengolahan dan anlisis data maka penulis dapat menyimpulkan hasil 
penelitian sebagai berikut: Terdapat pengaruh yang signifikan dari penggunaan media pembelajaran swimming board dalam pengembangan psikomotor karena swimming board memberikan daya apung pada saat melakukan latihan gerakan dasar kaki gaya bebas sehingga gerakan menjadi lebih halus.

Selanjutnya terdapat pengaruh yang signifikan dari penggunaan media pembelajaran swimming board dalam pengembangan kognitif dan afektif. Secara kognitif peserta didik dapat mengetahui penggunaan swimming board secara tepat guna dengan merujuk kepada tata cara penggunaan latihan menggunakan swimming board yang telah di program oleh peneliti. Secara teknik siswa dapat mengetahui gerakan mengambil napas dengan menggunakan swimming board sedang secara afektif siswa dapat menjalankan instruksi dengan baik. 


\section{Daftar Pustaka}

Ali, M. (2011). Memahami Riset Prilaku Dan Sosial. Cetakan Kedua. Bandung: CV. Pustaka Cendekia Utama.

Burns, J.A (2013). More may drown without better swimming lessons [Online]. Tersedia: http://www.bbc.co.uk/news/education-22615032. [27 Desember 2013].

Boyke, M (2013). Aktivitas Aquatik. Bahan Ajar Pada Mata Kuliah Renang. Bandung: Universitas Pendidikan Indonesia

Hamalik, O. (1995). Kurikulum dan Pembelajaran. Jakarta: Bumi Aksara

Lutan, R. (2001). Mengajar Pendidikan Jasmani, Pendekatan Pendidikan Gerak di Sekolah Dasar. Jakarta: Departemen Pendidikan Nasional

Mulyanto, R. (2010). Managemen pembelajaran metode block practice dan prinsip dap terhadap keterampilan renang gaya dada siswa kelas ïi sekolah dasar negeri neglasari kecamatan situraja kabupaten sumedang. Tesis. Pada Program studi pendidikan olahraga. Universitas Pendidikan Indonesia. Tidak diterbitkan

Murni, M. (2000). Renang. Jakarta: Departemen Pendidikan Nasional. Direktorat Jenderal Pendidikan Menengah.

Riduwan. (2010). Belajar mudah Penelitian Untuk. Guru, karyawan dan peneliti Pemula. Bandung : CV. Alfabeta

Sugiyono (2009). Metode pendidikan-pendekatan kuantitatif, kulaitatif dan R\&D .Bandung: cv alfa beta

Suherman, A. (2001). Dasar-Dasar Penjaskes. Jakarta: Departemen Pendidikan Nasional dan Kebudayaan.

Surahkmad. D.W, (1989). Metode Penelitian Pendidikan. Bandung: Tarsito.

Triaplianto. (2010). Pengarub Pembelajaran renang gaya dada dengan menggunakan papan pelampung dan bantuan teman. Tesis pada universitas negeri semarang. Tidak diterbitkan.

Thomas, D.G. (2006). Renang Tingkat Pemula. Jakarta: Rajagrafindo. 